\title{
Bill and Marge Franklin
}

\author{
Beverly Sauer ${ }^{1}$ (D)
}

Received: 6 July 2016 / Accepted: 12 July 2016 / Published online: 26 July 2016

(C) Springer-Verlag Berlin Heidelberg 2016

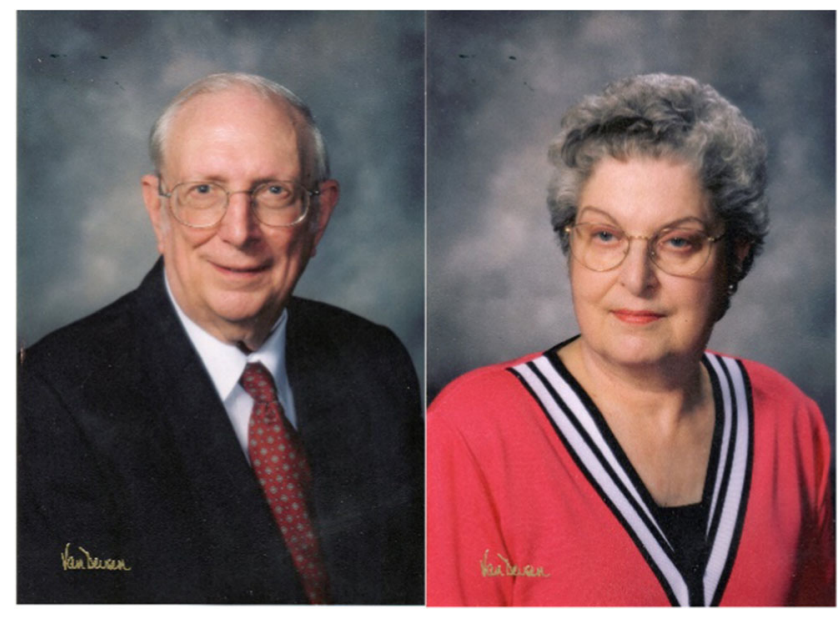

The LCA community marks the passing of two pioneering members, Bill and Marge Franklin, who together did so much to advance the field of life cycle assessment (LCA) and served as mentors to many professionals over their long careers. Marge passed away in February 2011 and Bill in May 2016.

Bill and Marge met at the University of Kansas (KU), where in 1956, Marge was the first woman to graduate from the aeronautical (aerospace) engineering program. Bill earned a B.S. in Geological Engineering from KU in 1957 and an M.S. in Industrial Administration from Purdue University in 1965. During their time at KU, Bill and Marge worked

Beverly Sauer

beverly.sauer@erg.com

1 Franklin Associates, A Division of ERG, 4200 Somerset Drive, Suite 132, Prairie Village, KS 66208, USA together on The Kansas Engineer student publication, where each served as editor.

Bill spent some time in the oil industry and then went to work at Midwest Research Institute (MRI) in Kansas City. At MRI, he gained national recognition in the field of solid waste management and participated in some of the first published national studies of markets for recovered materials. In 1969, a packaging engineer at The Coca-Cola Company came to MRI with an idea he had conceived of a comprehensive cradle-tograve analysis of beverage packaging options. Bill was one of the MRI staff members who developed the complex methodology necessary to carry out the study, which was the first life cycle study (known then as a resource and environmental profile analysis, or REPA) conducted in North America. Bill recognized the importance and potential of this exciting new field, and in 1975, he and Marge founded Franklin Associates, Ltd., a consulting firm specializing in life cycle assessment and solid waste management.

Bill participated in the international Society of Environmental Toxicology and Chemistry (SETAC) workshops that began in 1990 and served on the U.S. Technical Advisory Group for the development of the ISO 14040 LCA standards. In 2001, under Bill's leadership, Franklin Associates joined with The Athena Sustainable Materials Institute and Sylvatica to serve as prime consultants to the National Renewable Energy Laboratory (NREL) for the first phase of the development of the U.S. Life Cycle Inventory database, a landmark project in the effort to make high-quality life cycle inventory data freely accessible to all life cycle practitioners. Bill was a longtime member of the Advisory Council of the American Center for Life Cycle Assessment (ACLCA) and helped develop the ACLCA's LCA Certified Professional exam.

Bill was an extrovert who was passionate about LCA, and he spent hours on the phone with colleagues and clients talking about projects and how to advance the science and 
increase the use of LCA. Over his career, he conducted and managed hundreds of studies for private companies, industry associations, and government agencies and made dozens of presentations on LCA to U.S. and international audiences. It was rare to go through an airport with Bill and not run into someone he knew. He loved to read journals and trade publications, and each of his employees had a bulging folder of clippings Bill had put in their inbox to make sure everyone stayed up to date.

As co-owner of Franklin Associates, Marge was internationally respected for her expertise in the field of municipal solid waste and material flow methodology. The U.S. EPA's Sustainable Materials Management report (known for many years as the Municipal Solid Waste Characterization study), an important resource to those in the solid waste management field as well as the LCA community, has been prepared by Franklin Associates for many years using the methodology largely developed by Marge.

Bill and Marge were also very active outside of Franklin Associates. Bill served as Mayor of Prairie Village, Kansas from 1973 through 1979, and was honored with a city park bearing his name. Some of his other community leadership roles included serving on the City Council, the Board of County Commissioners, and the Johnson County Library Foundation. Marge had a passion for genealogy and produced a thoroughly-researched volume of her family history as an enduring legacy for future generations. She and Bill worked genealogical research into several of their vacation trips, particularly to New England and the UK, where Marge recounted how she was lucky to survive Bill's tendency to forget to drive on the "wrong" side of the road.
Bill and Marge were lifelong proud supporters of KU and avid Jayhawks fans. During his time at KU, Bill was president of Theta Tau professional engineering fraternity, and in 2004, he was inducted into the Theta Tau Hall of Fame for his outstanding contributions to his profession and to Theta Tau. In 2008, the American Center for Life Cycle Assessment presented him with a special award recognizing him for his leadership and lifelong service and achievement in the field of life cycle assessment. Marge served in numerous leadership roles during her time at KU and was the first woman in the USA to be initiated into the Sigma Tau engineering honor society. She continued to show her deep appreciation for her KU education by serving on several boards at the university, especially the Engineering Advisory Board. She was a strong and supportive advocate encouraging other women to pursue engineering as a career. To honor her many educational and professional achievements, in 2003 she was awarded the KU Distinguished Engineering Service Award. An engineering scholarship in Marge and Bill's name is established at $\mathrm{KU}$, and information on making a donation can be found at the KU Endowment website (www.kuendowment.org). Contributions should be designated for the Marjorie A. and William E. Franklin Women in Engineering Scholarship.

Bill and Marge leave a legacy of professionalism, generosity, service, and integrity. They will live on not only in their enduring technical contributions to the fields of LCA and municipal solid waste management but also in the hearts of the many friends they made over their long careers. 